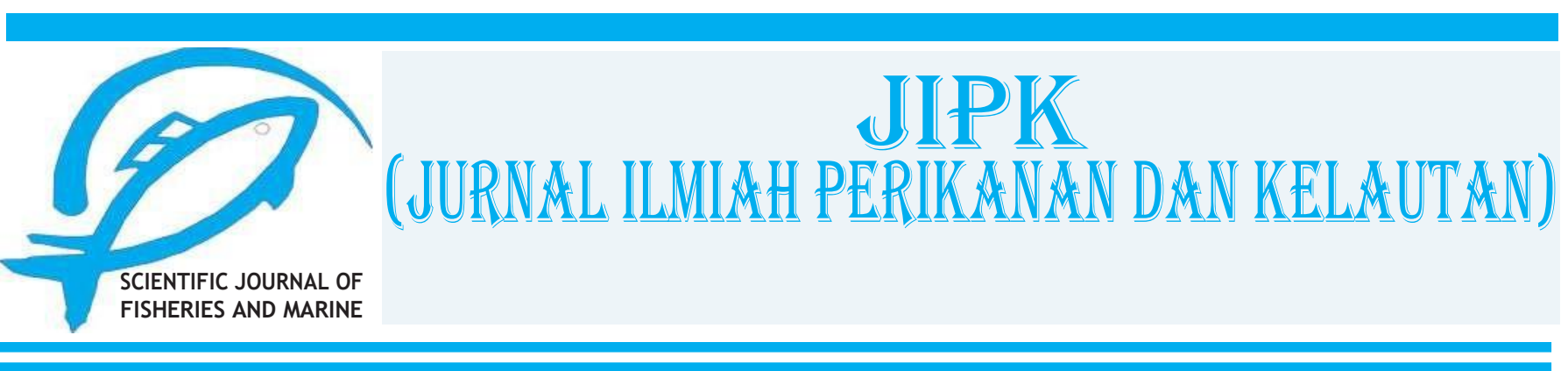

Review Article

\title{
Trends in the Uses of Spirulina Microalga: A mini-review
}

\author{
Aondohemba Samuel Nege ${ }^{1,2}$, Endang Dewi Masithah ${ }^{3}$ (D), Junaidi Khotib ${ }^{4}$ \\ ${ }^{1}$ Fisheries and Marine Biotechnology Programme, Faculty of Fisheries and Marine, Universitas Airlangga. Indonesia. \\ ${ }^{2}$ Department of Fisheries and Aquaculture, University of Agriculture, P.M.B 2373, Makurdi, Nigeria. \\ ${ }^{3}$ Department of Marine, Faculty of Fisheries and Marine, Universitas Airlangga. Indonesia. \\ ${ }^{4}$ Department of Clinical Pharmacy, Faculty of Pharmacy, Universitas Airlangga. Indonesia. .
}

\section{OPEN ACCESS \\ $\underline{\text { ARTICLE INFO }}$ \\ Received: January 21, 2020 \\ Accepted: February 11, 2020 \\ Published: March 11, 2020 \\ *) Corresponding author: \\ E-mail:endang_dm@fpk.unair.ac.id}

\section{Keywords:}

research trends

health

food

environment

spirulina

This is an open access article under the CC BY-NC-ND license (http://creativecommons.org/licenses/by-nc-nd/4.0/)

\begin{abstract}
There is a need to have a single document that summarises the present day uses of Spirulina. In this review, the research trend on the health and other applications of Spirulina microalga was critically evaluated. In terms of the health uses, antioxidant, antibacterial, and immunostimulant effects of Spirulina were emphasized. Other uses of the microalga discussed include the use of Spirulina for human and animal food, bioenergy, pollution and ecotoxicology control, cosmetics, bioplastics and biofertilizers. Literature search revealed that Spirulina polysaccharides, phycocyanin size and content play a role in antioxidant activity and DNA repair. The double bonds and positions of $-\mathrm{COOH}$ and $-\mathrm{OH}$ in Spirulina phenol content and $\gamma$-linolenic fatty acids ( $\gamma$-LFA) have antimicrobial activity. Some compounds in Spirulina improve immune, increase survival rate and enhance distribution of proteins like hepcidin and TNF- $\alpha$ in animal models. High protein, vitamins, fatty acids (FAs) and glycoproteins in Spirulina are easily digestible due to its lack of cellulose and can improve human and livestock growth. Spirulina produces biodegradable and non-toxic biodiesel and useful co-products. Absorption of heavy metals by chemisorption occurs in Spirulina. Phycocyanin and $\beta$-carotene of Spirulina increase skin health, Spirulina also cause high cell proliferation and aids wound healing. Bioplastics produced from Spirulina are biodegradable, non-toxic with high blends. Biofertilizers from Spirulina have little or no residual risks, adds soil Nitrogen through Spirulina Nitrogen fixation ability. In addition, the survey of published works on Spirulina for the past two decades indicates that more research is been carried out in recent years using Spirulina, especially studies involving its health potentials and those concerned with molecular analysis. In conclusion, Spirulina is an exceptional commodity with numerous applications, and probably, some of its compounds causing those effects are yet to be isolated and that is one area for further research.
\end{abstract}

Cite this as: Nege, A. S., Masithah, E. D., \& Khotib, J. (2020).Trends in the Uses of Spirulina Microalga:A Mini-Review. Jurnal Ilmiah Perikanan dan Kelautan, 12(1):149-166. http://doi.org/10.20473/jipk.v12i1.17506 


\section{Introduction}

Microalgae, equally known as phytoplankton refer to all the aquatic autotrophs that live in suspension in the water column and the name encompasses several phyla which are mostly eukaryotes with the inclusion of photosynthetic prokaryotes called cyanobacteria (Widowati et al., 2017). Microalgae are obviously very important for their role in food production in aquatic ecosystem as components of the food chain. Early studies on phytoplankton were focused on their use for food by fish and other aquatic organisms, both in their natural habitats and in aquaculture (Brown et al., 1997) however, microalgae are being used for other numerous purposes presently. In mid 2000s, the world Spirulina production for human use was estimated to stand at more than one thousand metric tons annually (Khan et al., 2005). However, it is obvious that more production is needed since it has numerous uses including the pharmaceutical industry where a major challenge with drug active ingredients from natural sources is their insufficient supply. In terms of quantity produced, USA is reported to be leading, then Thailand, India, Japan followed by China (Khan et al., 2005).

Spirulina is a "blue-green" photolithoautotroph, meaning it is able to derive energy from sunlight and use carbon dioxide as its carbon source (Perry et al., 2002). It obtains minerals from the inorganic sources of the environment and similar to other cyanobacteria, Spirulina is gram negative with a cell membrane, cell wall and an outer membrane. Spirulina has been known for its food benefits for numerous years even before its rediscovery three decades ago (Barnett, 2007) as the sale of little biscuits of dried Spirulina biomass known as "Dihe" decades ago in a market in present day Chad is a good example (Cliferri, 1983; Perry et al., 2002). Arthrospira maximus obtained from Lake Texcoco (around present day Mexico) which was added into bread by the Spanish Conquistadors is another old instance of the use of Spirulina for food by man (Cliferri, 1983).

The phylum cyanobacteria otherwise known as "blue-green algae", encompasses photosynthetic prokaryotes which have the capability to produce chlorophyll $a$ (Whitton and Potts, 2000). The ability of cyanobacteria to photosynthesize "anoxygenically" in sulphide conditions has been established (Klatt et al., 2015) however, on a general note; they use water as electron donor for photosynthetic process which results in the release of oxygen. The taxonomic classification of cyanobacteria was done based on their ability to synthesize phycocyanin, a blue phycobilin pigment. The bluish colouration of these organisms which was the reason for their nomination as "blue-green algae" is as a result of the blue phycobilin pigment they possess (Müling, 2000).

The taxonomic relationship of cyanobacteria with bacteria has long been recognized since more than 100 years ago by researchers like Cohn as well as De Bary and also, between 1930 and 1965; the fundamental differences in organization of their cells and those of eukaryotes was elucidated by Stanier and Van Niel, as Stanier later provided a convincing submission that cyanobacteria possess the same prokaryotic cellular organization as do bacteria. His proof led to the current generally accepted nomination of cyanobacteria which can be traced back to 1979. In 1932, Geitler earlier produced a comprehensive treatise which recognized about 143 genera of cyanobacteria containing 1300 species on the basis of observations on field material, as reported by Müling, (2000).

The common species of Spirulina (Arthrospira and Spirulina) belong to the same order Oscillatoriales which encompasses all non-heterocystous, filamentous cyanobacteria that reproduce by binary fusion in plane without the production of alkinetes. The possession of helical trichome morphology by Arthrospira and Spirulina is what distinguishes them from oscillatoriaceean genera. The life cycle of Arthrospira represents a typical and simple life cycle of the Oscillatoriales. The apex part of the trichome usually breaks as a result of the formation of specialized cells called necridia, the necridia are the ones that undergo cell lysis. The above account on Arthrospira platensis is presented as reported by Cifferi as well as Castenholz in the early and late 1980s respectively and as cited in Müling (2000). The necridia are distinguishable by their lack of pigments and biconcave shape. Howbeit, irrespective of the strain concerned, necridia are not often noticed and fragmentation of the trichomes may hence occur without sacrificing a cell (Müling, 2000). The resulting cells called the hormogonia (usually short chains of cells or a single cell) are very motile, giving rise to a new trichome through the process of binary fusion which is often vertical to the longitudinal axis of the trichome.

A diagram showing the reproductive process in Spirulina as explained above is presented below in 
Figure 2, before the diagram is the taxonomic classification of Spirulina (from kingdom to species) while the preceding diagram (Figure 1) shows some filamentous Spirulina cells under microscope (photo taken during one of our laboratory works).

Brief Biological Classification of Spirulina platensis:

$\begin{array}{ll}\text { Kingdom } & \text { : Eubacteria } \\ \text { Subkingdom } & \text { : Negibacteria } \\ \text { Phylum } & \text { : Cyanobacteria } \\ \text { Class } & \text { : Cyanophyceae } \\ \text { Subclass } & \text { : Oscillatoriophycidae } \\ \text { Order } & \text { : Spirulinales } \\ \text { Family } & \text { : Spirulinaceae } \\ \text { Genus } & \text { : Spirulina } \\ \text { Species } & \text { : Spirulina platensis }\end{array}$

Source: Algae Base, last accessed: 17th April, 2019.

Raceways with shallow depths are commonly used for commercial production of Spirulina, howbeit; there are also scenarios of harvesting Spirulina from their natural populations for commercial use. "Semi-natural" cultivation involves harvesting during the day and night and allowing its biomass to double within 3-4 days. Filtration is done and the Spirulina biomass is homogenized and pasteurized followed by a spray-drying process (Oliguin, 1986).

Laboratory cultivation on other hand is mostly done in bottles at experimental scale as all the needed conditions for algal growth are provided artificially. Basically, 8 environmental factors influence Spirulina productivity including temperature of $\pm 30^{\circ} \mathrm{C}$, stirring speed, luminosity, inoculation size, dissolved solids (10-60 g/litre), macro and micronutrients availability, pH of 8.5-10.5 and water quality (Ciferi, 1983; Ayala, 1998).

Unarguably, they are numerous research reports and reviews on the microalga Spirulina, however, single reviews discussing "all" its applications are still scarce. Also, newer applications of Spirulina have evolved over time; hence compiling a single review that discusses trends in its applications is very important. It is in this regard that this review was designed to discuss the present day uses of Spirulina from already published works in reputable sources and from the practical experiences of the authors.

\section{Use of Spirulina}

Long before the development of current scientific knowledge, microalgae have played important roles in the life of human beings. Studies covering the trends in applications of Spirulina over different decades are presented below.

\subsection{Health and Pharmaceutical Uses of Spirulina}

Many works have revealed the health and pharmaceutical roles of Spirulina. Khan et al. (2005) reported that some species of Spirulina exhibitbiomodulating and immunomodulating properties; S. platensis has a positive regulatory effect on immune system as it concerns the innate and specific immunity. Both human and animal immune systems have been reportedly enhanced via Spirulina intake (Khan et al., 2005) and many researchers have investigated and reported the anticancer and other effects of Spirulina (O'Shaughnessy et al., 2002; Grawish, 2008).

\section{Spirulina as an Antioxidant Agent}

The antioxidant ability of Spirulina and some other microalgae is well documented and this could be one of the reasons for their current popularity. According

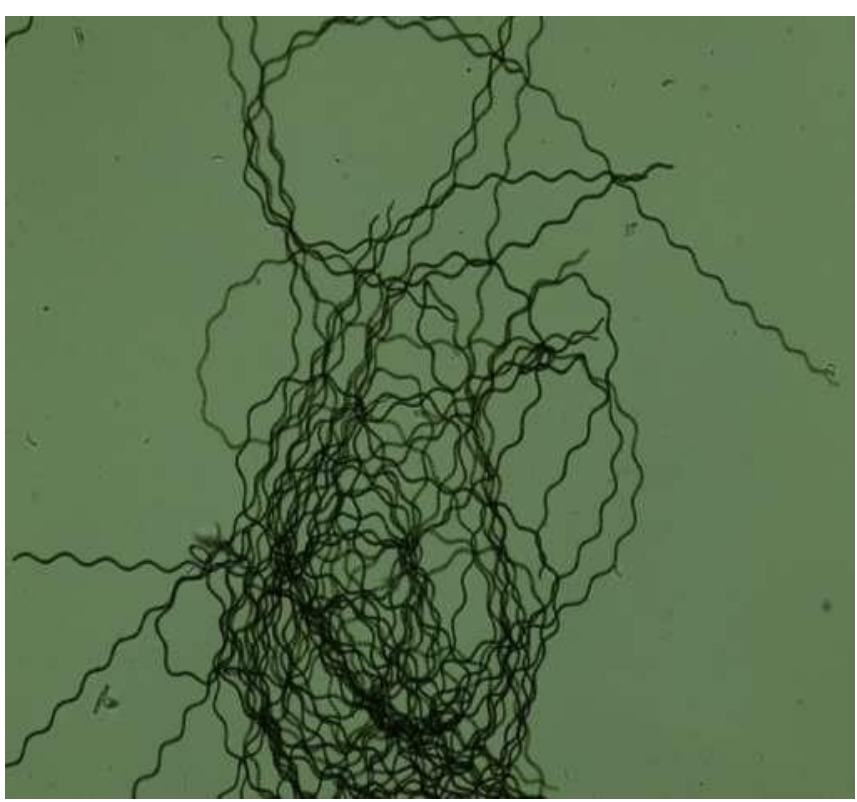

Figure 1. Microscopic view of Spirulina platensis. Authors' Lab work (2019). Mag. $=40 x$. 
Fig. 1.1A

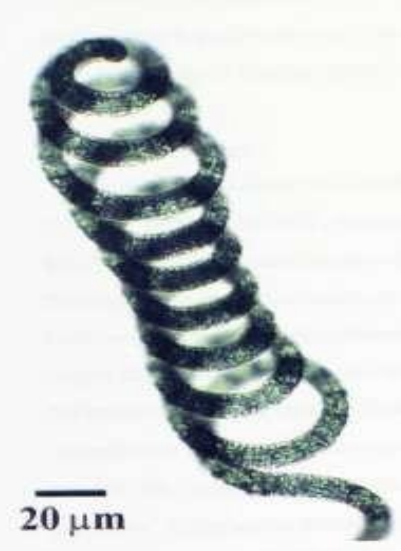

Fig. 1.2A

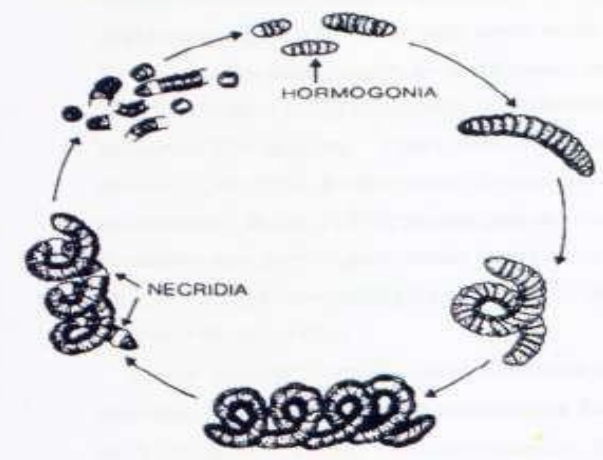

Fig. 1.1B

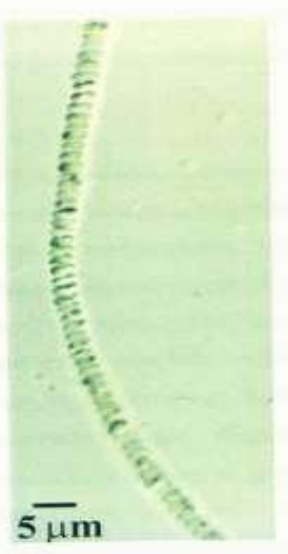

Fig. 1.2B

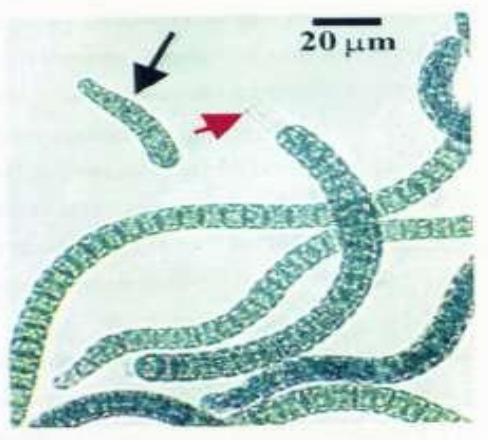

Figure 2. Microscopic image showing reproduction in Spirulina (Arthrospira platensis) (Müling, 2000).

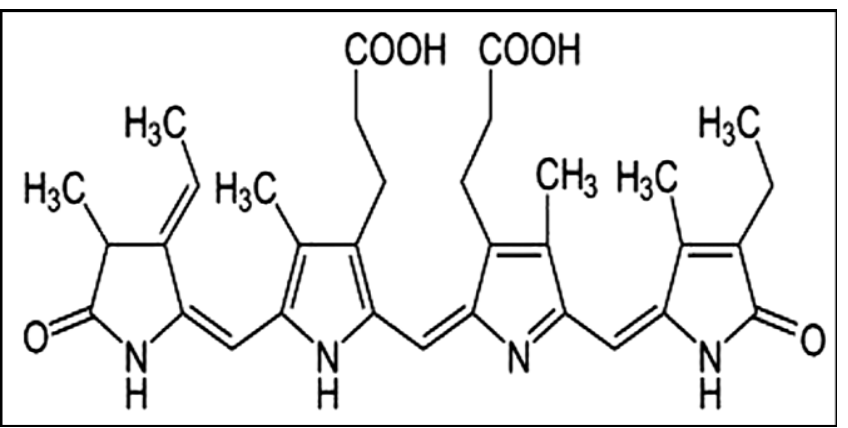

Figure 3. Chemical structure of C-phycocyanin (Müling, 2000)

to O'Shaughnessy et al. (2002), carcinogenic processes can be reversed or interrupted with some specific agents prior to the onset of cancer; these agents could be synthetic or natural. The reports by Grawish (2008) revealed a tumor suppressive effect of Spirulina extract in hamster cheek pouch mucosa as a result of repair to the DNA damage.

The DNA repair is as a result of endonuclease activity that can be triggered by unique polysaccharide content of Spirulina (Grawish, 2008). Cyclooxygenase-2 (Cox-2) and Cyclooxygenase-1 (Cox-1) are the two observed forms of a bifunctional enzyme (Hoseini et al., 2013). Spirulina species produce C-phycocyanin which functions as a selective inhibitor of Cox-2, the inhibition is known to occur as a result of the big and conformational structure of phycocyanin, which aids its proper binding to the active spot of Cox-2 (Reddy et al., 2000).

Recently, it has equally been revealed that selenium enriched S. platensis interrupted MCF-7 (human breast cancer cells) growth. The study by Bermejo et al. (1997) reported an excellent antioxidant activity in S. platensis as their work revealed protein extracts of $S$. platensis that scavenged peroxyl and hydroxyl radicals and equally had an inhibitory activity on lipid peroxidation. Additionally, reports by Gad et al. (2011) indicated the strong inhibition of ferrozine- $\mathrm{Fe}^{2+}$ complex forma- tion brought about by the chelating activity of Spirulina which results from its antioxidant compounds which are electron donors.

\section{Spirulina as an Antibacterial}

Since Spirulina contains many compounds including those with chromophore groups and bonds, this could form the bases for a thought about antimicrobial 


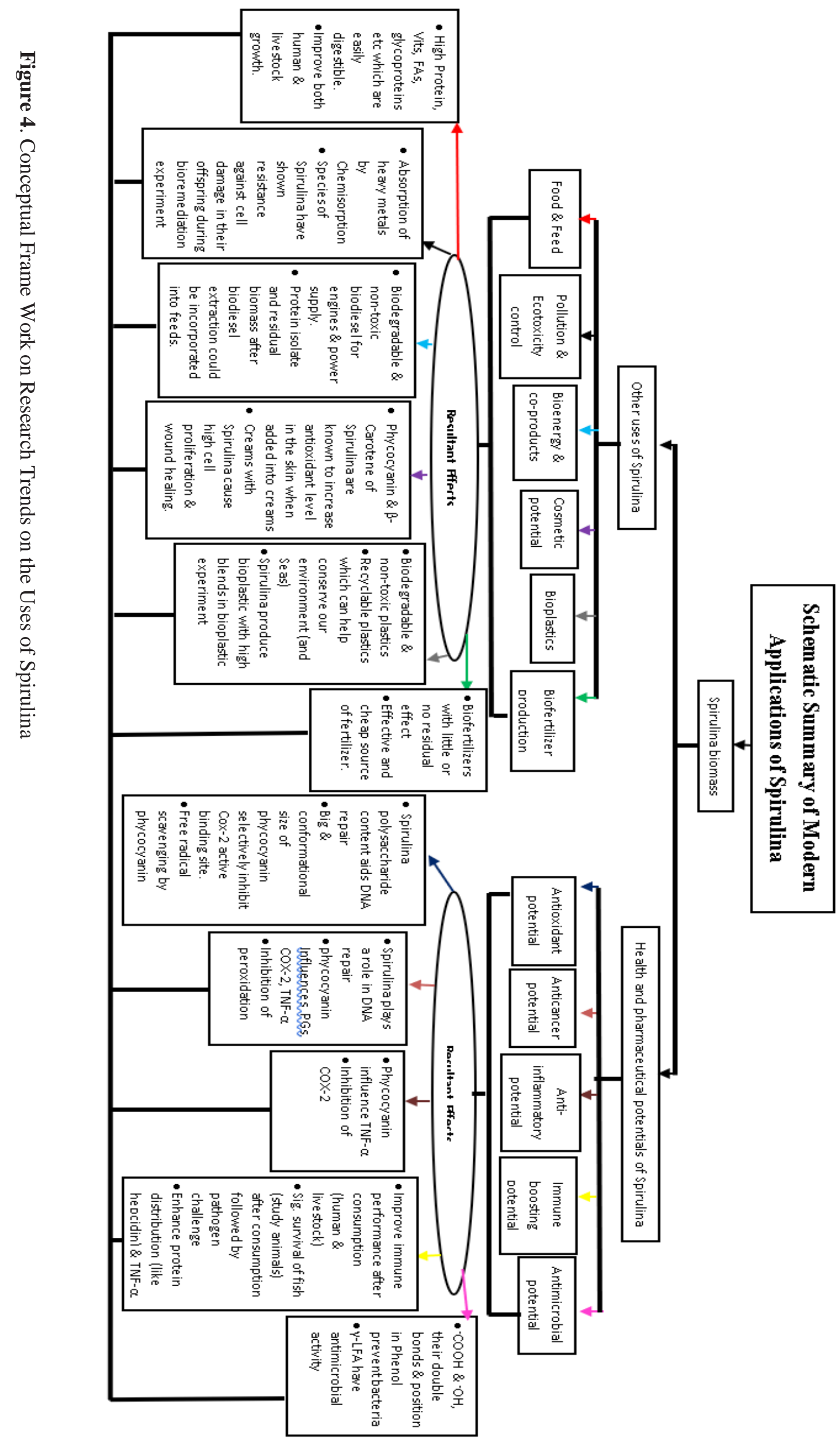


activity in Spirulina apart from other medicinal potentials often demonstrated by Spirulina. The study by Demule et al. (1996) observed that antimicrobial activity of methanolic extract of Spirulina is as a result of the availability of $\gamma$-linolenic fatty acid which is an active antimicrobial fatty acid available in high quantity in the alga extract.

The antimicrobial activities of Spirulina extract on some bacteria; Escherichia coli, Staphylococcus aurus, Aspergillus niger (a fungus) and Candida albicans (yeast) indicated that $C$. albicans were most sensitive to all the fractions of Spirulina tested (Mendiola et al., 2007). According to Hoseini et al. (2013), such antimicrobial activity may have a relationship with the synergistic effect of fatty acids. In addition, some studies on the antibacterial effect of Spirulina have proven it superior to some other natural antibacterial; Ali \& Doumandji (2017) reported that methanol extract of Spirulina had a wider-spread spectrum of antimicrobial activities and appeared more promising against Gram positive bacteria compared to Chlorella which appeared more promising on Gram negative bacteria.

Manigandan and Kolanjinathan (2017) who studied the antibacterial activity of different solvent extracts of Spirulina using the disc diffusion and agar well diffusion methods reported higher antibacterial activity in methanol extracts using both methods however the results of Nege et al. (2020) on antibacterial effects two natural products showed that hexane fraction had the highest inhibition zone on Staphylococcus aureus among the tested crude and fractional extracts from Spirulina. These varied observations are perhaps pointers to the fact that different solvents and bacterial groups (Gram negative or positive), geographical location amongst other factors can influence the antibacterial activities of a natural product like Spirulina.

From our literature search, not many literatures focused on the antibacterial mechanism of Spirulina specifically, as most reports generally explained the antibacterial mechanism of microalgae. Katircioglu et al. (2005) stated that the antimicrobial activity of microalgae can be elucidated by the presence of cyclic peptides, lipopolysaccharides and alkaloids, the activity maybe as a result of toxins produced by microalgae cells since some blue green algae are known to produce toxins with potent pharmaceutical uses (El-Sheekh et al., 2014). Alves et al. (2013) submitted in their study on the mechanism of anti-MRSA that only phenolic acids (benzoic and cinnamic acid derivatives) were the main compounds with anti-MRSA activity at a point in their research, illustrating the relevance of the carboxylic group in the molecular structure (proton recipient). The report by the authors added that all the compounds with anti-MRSA activity possessed an $-\mathrm{OH}$ (proton donor) and an $-\mathrm{OCH}_{3}$ (proton acceptor) groups in the para and meta positions of the benzene ring respectively and the activity was observed to decrease in the absence of $-\mathrm{OCH}_{3}$ group in the meta position ( $p$-coumaric acid). However, the absence the above group in the structure of 2,4-dihydroxybenzoic acid was seemingly overlapped by $-\mathrm{OH}$ substitution in ortho position of the benzene ring. In addition, only $-\mathrm{OCH}_{3}$ (proton acceptor) or $\mathrm{H}$ in position 5 of the benzene ring permitted anti-MRSA activity since the activity disappeared upon presentation of $-\mathrm{OH}$ in that position.

Although the mechanism explained by Alves et al. (2013) was using phenolic compounds identified in wild mushrooms, there is a tendency that the antibacterial mechanism of phenolic compounds from Spirulina will follow a similar pattern.

\section{Immunostimulant and Growth Promotion in Animals}

The relatively cheap cost of Spirulina makes it a good additive in animal feed for improved growth and immunity amongst other reasons. The study by Abu-Elala et al. (2016) and those of others revealed improved immune system in fish fed Spirulina supplemented diet even after a pathogen challenge compared with groups fed "normal" diet. Abu-Elala et al. (2016) recorded a significant survival rate and the distribution of proteins such as TNF- $\alpha$ in Spirulina fed group against the control, these suggest that one or more of the components in Spirulina may have caused those positive effects. In addition, Bashandy et al. (2016) also demonstrated the ability of S. platensis dose of $300 \mathrm{mg} / \mathrm{kg}$ to reduce the oxidative stress, sperm abnormalities and testicular damage in rats induced by Arsenic.

The findings of the above authors justify the submission that Spirulina also has immunnostimulant as well as growth promotion potentials. Similarly, Amer (2016) found that S. platensis supplemented groups revealed higher levels of Lysozyme, Catalase and IgG compared to others. Obviously the immunostimulant and growth mechanism of Spirulina in the systems of animal models seems to involve different and many channels, for example the study by Macias-Sancho et al. (2014) reported that Spirulina stimulated the immune system of shrimp by direct reduction in apoptosis while Noman (2018) stated that Spirulina has potential to augment components of mucosal and systemic immune system via the activation of non-specific immune. The aqueous extract of Spirulina have reportedly influenced defence (immune) system through enhancement of the activity of phagocyte as well as stimulation of natural killer (NK) cells (Ravi et al., 2010).

The findings by Nakono et al. (2003) may have earlier justified the reasons for increased animal 
immune upon consumption or treatment with Spirulina as the authors observed that the lack of cellulose in the cell structure of Spirulina makes it easily digestible therefore increasing fish appetite, improving their feed intake and digestibility which in turn enhances the overall health of the fish that subsequently leads to the fish' ability to defend infections via stress level reduction.

\subsection{Spirulina for Human Food and Animal Feed}

Spirulina contain high quantities of valuable proteins, vitamins, indisputable amino acids, beta carotene, essential fatty acids, mineral components, polysaccharides, sulpholipids and glycoproteins among other components (Glazer, 1988; Tandeau de Marsac and Cohen-Bazire, 1997; Fairchild and Glazer 1994) hence the addition of Spirulina to diets can provide a wide range of valuable nutrients (Khan et al., 2005). All edible species of Spirulina have certain peculiarities, they are regarded as a functional group which refers to a product acquired from a natural source that when consumed, it is very likely to provide health benefit and enhance system functions. Spirulina also has a high content of B vitamins, minerals, calcium, magnesium, iron, potassium, manganese, and zinc.

Moreover, the study by Agustini et al. (2016) on addition of Spirulina on ice and soft cheese and their sensory analysis proved that incorporation at 1 and $1.2 \%$ Spirulina was best for cheese and ice cream respectively. The same author in 2017 (Agustini et al. 2017) found in another study that incorporation of $9 \%$ Spirulina revealed a significant effect in elasticity, fat, water, $\beta$-carotene, protein, ash, carbohydrate content and sensory (hedonic) effects.

Khan et al. (2005) referred to Spirulina as a suitable matrix for biotechnological incorporation of new food trace element preparation. It is an important source of essential fatty acid; the gamma linolenic acid (GLA) (Colla et al., 2004; Otles and Pire 2001) as $10 \mathrm{~g}$ of Spirulina harbours over $100 \mathrm{mg}$ of GLA (Nichols \& Wood, 1968; Roughhan, 1989). The high quantity of riboflavin (Vitamin $\mathrm{B}_{12}$ ) in Spirulina is another reason for its great nutritional value since this can be a very useful source of vitamin $B_{12}$ to vegetarians who often lack this vitamin in their diets (Dagnelie et al. 1991).

It is not surprising that the United Nations (UN) referred to Spirulina as "the most ideal food for mankind", the San Francisco Medical Research Foundation called it "the immune system miracle worker" while the Food and Agriculture Organization (FAO) of the UN called it "food for the future" (Agrotech, 2012).

\section{Applications of Spirulina in Aquaculture}

As of date, numerous works have been docu- mented on the use of Spirulina as a complete or partial supplementation for protein and/or other nutrients in aquaculture via aquaculture feeds. As far back as 1994, the reports of El-Sayed indicated that Seabream (Rhabdosargus sarba) fed on up to $50 \%$ of Spirulina was indifferent and their feed conversion efficiency not superior to those fed exclusively fishmeal.

In 1996, Abalone (Haliotis midae) revealed significantly higher growth after being fed with Spirulina and fishmeal compared to feed made from soybean meal, casein, dried Ecklonia maxima and torula (Britz, 1996). Moreover, more recent works have equally supported the above observations on the incorporation of Spirulina into fish diets. El-Sheekh et al. (2014) who studied the effect of Arthrospira platensis on the growth and carcass of hybrid red Tilapia observed and recommended that $75 \%$ Spirulina can conveniently substitute fishmeal-based diet with increased feed conversion ratio as well as protein value in proximate composition of the carcass. A 10\% replacement of fishmeal with Spirulina in the feeding trial of common carp (Cyprinus carpio) gave significantly higher body weight as against other treatments and the control (Abdulrahman et al., 2014), on the other hand Ibrahem et al. (2013) observed improved feed conversion ratio and growth rates in striped jack and Tilapia (Pseudocaranx dentex and Oreochromis niloticus). The findings of Amer (2016) showed that Tilapia supplemented with $1 \%$ S. platensis gave lower FCR but higher body weight compared to other groups and the control.

In addition, the study by Teimouri et al. (2013) on the effects of $0,2.5,5,7.5$ and $10 \%$ S. platensis and synthetic astaxanthin $(50 \mathrm{mg})$ diets on the fillet and skin pigment including growth performance of rainbow trout (Onchorhynchus mykiss) and found that incorporation of $10 \%$ S. platensis gave the highest carotenoid deposition in fillet and skin, implying Spirulina can be used as a substitute for synthetic astaxanthin in the diets of rainbow trout. In terms of cost reduction in fish feed, ElSheekh et al. (2014) observed that the utilization of $A$. platensis meal (75\% inclusion) in the feed of red Tilapia resulted in a decrease in feed expenditure (cost $/ \mathrm{kg}$ feed) and an incidence cost was accompanied with increased profit index. In addition, Nakono et al. (2003) earlier reported that the absence of cellulose in the cellular structure of Spirulina makes it easily digestible thereby increasing the appetite of the feeding organism (fish in the case of their study), improving both feed intake and nutrient digestibility which in turn enhanced fish health as well as increased their capacity to defend infections via the reduced level of stress. As a result of these positive findings, many authors in this area of have recom- 
mended Spirulina as a good and economical nutritional supplement in aquaculture.

\subsection{Bioenergy production}

Indeed the rapid depletion effect of fuel obtained from fossils has given rise to the search for an alternative and sustainable fuel that can replace the "conventional fuel" to eliminate energy crises with little or no environmental effects (Rahman et al., 2017). To achieve the above, many scientists are working day and night in search of eco-friendly and sustainable energy sources, hence the development of a renewable source of fuel still remains a serious issue globally.

Recently, biodiesel is becoming increasingly acceptable as an alternative available for researchers to supplement conventional fuel. Incidentally, the characteristics of biodiesel are highly similar to those of diesel and hence can fit at all points with diesel and biodiesel can be used in existing engines without a modification.

As a good feedstock, microalga is one of the most promising alternatives of conventional feedstock. Generally, algae contain a high level of oil compared to other feedstock. The report of Demirbas (2009) indicates that algae yields over 200 times oil per acre when compared to the best-performing plant or vegetable oils. In addition, biodiesel from algae is biodegradable, nontoxic, and renewable with great potential as a green alternative fuel for $\mathrm{Cl}$ engine. It equally has acceptable combustion and emission profile compared with petroleum fuel (Mata et al., 2010).

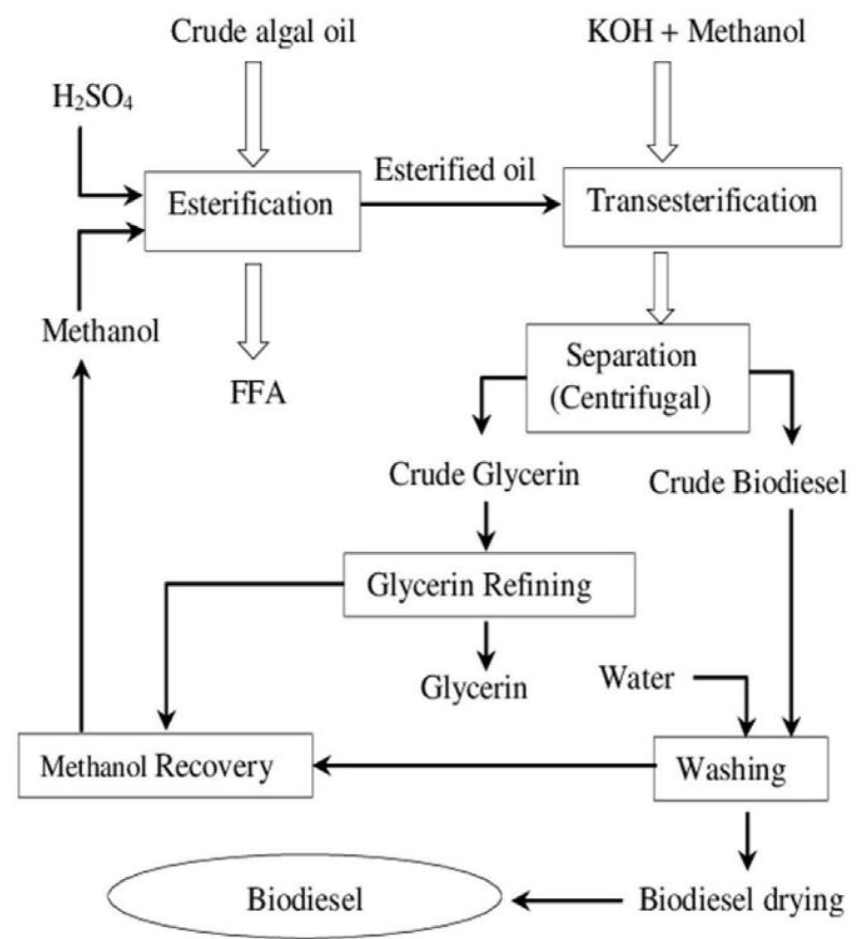

Figure 5. Biodiesel production flow chart (Rahman, et al., 2017).
In the study on Spirulina maxima by Rahman et al. (2017) molar ratio which is one of the optimization parameters for esterification indicated that $3: 1,6: 1$, 9:1, 12:1 and $15: 1$ molar ratios at $65^{\circ} \mathrm{C}$ with $1.5 \%$ sulphuric acid at $350 \mathrm{rpm}$ for a $2 \mathrm{~h}$ reaction period gave good results of acid value (AV) reduction from 8.2 to 3 $\mathrm{mgKOH} / \mathrm{g}$ with increased esterified oil yield to $22.2 \%$ during an increase in molar ratio from 3:1 to 12:1. However, further increase in molar ratio gave no reduction in $\mathrm{AV}$, possibly due to water production effects (Berchmans and Hirata, 2008). Deng et al. (2010) also obtained the above $22.2 \%$ at $12: 1$ molar ratio in acid esterification of Jatropha curcas L. seed oil. According to Rahman et al. (2017) the optimum methanol to algal oil ratio was 9:1 since it reduced AV to the lowest; from 10.45 to $1.21 \mathrm{mg}$ $\mathrm{KOH} / \mathrm{g}$.

\subsection{Pollution and Ecotoxicology Prevention/Control}

According to Murali and Mehar (2014), environmental pollution is but a product of industrial revolution. Environmental pollution is known to affect quality of life as well as environmental ecosystem. For several decades now, numerous attempts have been made to reduce environmental pollution and amongst those attempts is bioremediation. Bioremediation often involves the use of microorganisms for reduction of toxicity from harmful waste and heavy metals. This offers a solution to the management of solids by waste detoxification, the cost effectiveness of this technique and the environmental impact it offers makes it appear more attractive (Murali and Mehar 2014).

For the above reasons, various cyanobacteria species including Spirulina have been studied to assess their toxicity reducing ability. The ability of Spirulina to take up Dichlorodiphenyltrichloroethane (DDT) at concentrations of 10 and 50ppm was tested and it was able to assimilate approximately $65 \%$ (6-6.5 ppm) DDT at $10 \mathrm{ppm}$ and then about $80 \%$ (40ppm) of DDT at 50ppm concentration. Although more damage was observed on the Spirulina cells after incubation at 50ppm DDT apart from the detected residue but at 10ppm, less than $1 \%$ was observed (trace quantity of DDT).

The study by Chojnacka et al. (2005) on the mechanism of Spirulina in biosorption of metals including $\mathrm{Cu}^{2+}, \mathrm{Cd}^{2+}$ and $\mathrm{Cr}^{3+}$ indicated that chemisorptionsinstead of physical adsorption was the main mechanism for sorption of heavy metals by Spirulina. Maximum contribution of physical adsorption in the study was only 3.7\% while functional groups in the cell surface participated in the binding of metal ions by a biosorbent through equilibrium reaction. The findings of Rangsayatorn et al. (2002) showed that the uptake of heavy metals by Spirulina platensis was independent of the solution's tem- 
perature but dependent on its $\mathrm{pH}$ as the optimum $\mathrm{pH}$ of biosorption was reported as 7. Meanwhile, the maximum adsorption ability of Spirulina was recorded as 98.04 $\mathrm{mg} \mathrm{Cd}$ per biomass and the rate of heavy metal uptake was fast, $78 \%$ of the adsorbed metal occurred in the first 5 mins, indicating a high rate of heavy metal absorption by Spirulina. Not so many scientific articles have clearly explained the mechanism of pollutant uptake by Spirulina, however, Dwivedi (2012) summarized the mechanism of metal uptake by algae as a process occurring via adsorption as follows, firstly, a physical adsorption which involves a quick uptake of metal ions over the cell surface in few seconds or minutes followed by a slow transportation of the ions into the cytoplasm in a process referred to as chemisorption.

\subsection{Cosmetics}

The term cosmetics is quite broad and covers substances used for all forms of body painting like for religious or ornamental purposes (Novak, 2010). The Resolution RDC no. 79 of August 28, 2000 defines cosmetics as products made from natu- ral and/or synthetic substances to be used externally on human body parts such as hair system, nails, skin, teeth, mucous membrane of oral cavity and genitalia with the aim of perfuming, cleaning, altering their appearance, protecting them, correcting or keeping them in good condition.

Antioxidant defence of the skin is dependent on synergistic effects of different antioxidants like vitamins (Vit C, Vit $\mathrm{E}$ isoforms), nutrition and endogenous enzymes (superoxide dismutase: SOD and catalase, and GSH peroxidase: GPx). According to Gunes et al. (2017), S. platensis is a microalga with high phycocyanin and the pigment phycocyanin has been largely used as a natural blue colourant in cosmetics. The results of Gunes et al. (2017) on the effect of Spirulina extracts in cream on cytotoxicity and wound healing activities revealed high cell proliferation at concentrations of 0.1 and $0.05 \%$. Meanwhile the wound healing test showed a significant improvement as the groups administered cream incorporated with $S$. platensis extract improved significantly $(\mathrm{p}<0.05)$ compared to the control, the effect was highest at $1.125 \%$ Spirulina extract with more efficiency on the skin cells and wound closure.

\subsection{Bioplastics}

Plastics are obviously one among the most commonly used commodities around us. Consumers of

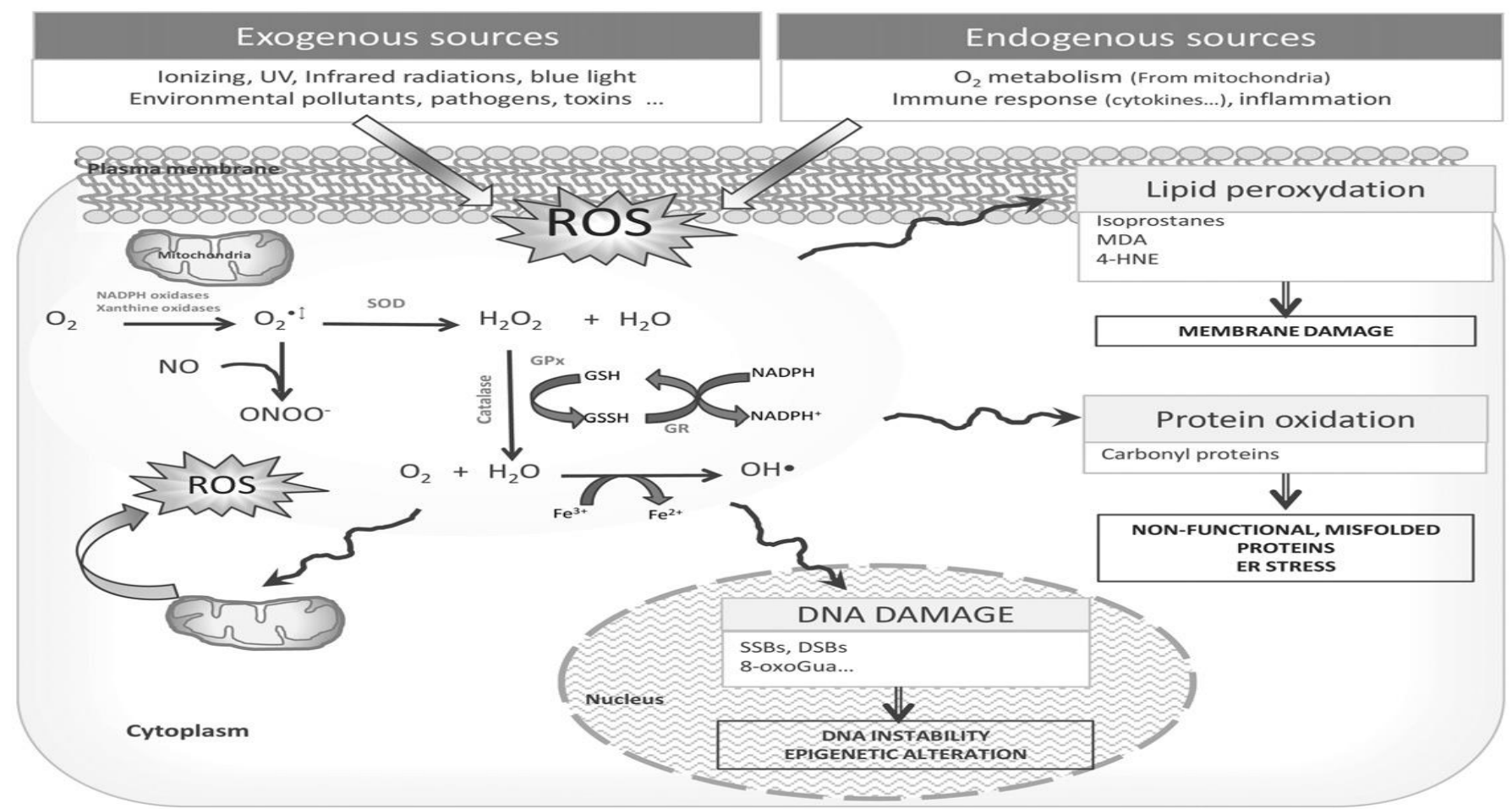

Figure 6. Summary of ROS pathways and their induced cellular damage. Cells of the skin face constant exposure to both endogenous and exogenous forms of ROS. Enzymes like xanthine oxidase or NADPH oxidase and the Mitochondria are endogenous sources of ROS. The cell is furnished with a variety of defense mechanisms for scavenging ROS. SOD catalyses the dismutation of superoxide resulting hydrogen peroxide while the reaction of catalase (CAT) with hydrogen peroxide trigger water and oxygen formation. Glutathione peroxidase (GPx) is known to reduce hydrogen peroxide. The reduced form of GSH is converted into oxidized glutathione (GSSG) at the point $\mathrm{H}_{2} \mathrm{O}_{2}$ is converted to water. Destroyed mitochondria yield more ROS in a reoccurring circle. Adapted from Berthon et al. (2017). 
this age need inexpensive, versatile and convenient materials for the production of plastics (Zeller et al., 2013). As at present, a major constituent of the world's plastic originates from petroleum which have a number of advantages such as high economies of scale and developed technologies (Iles and Martin, 2012).

Plastics are constantly used as a result of their strength which is combined with low weight, resistance to degradation by sunlight, water, bacteria and chemicals as well as their thermal and electrical insulation abilities (Zeller et al., 2013). Polystyrene which is one of the most largely utilized plastics has a very slow degradation rate in our environment. High impact polystyrene (HIPS) as a copolymer of polystyrene and polybutadiene is a cheap, easy to manipulate and easy to fabricate type of plastic material.

Despite these "advantages", the above plastic materials cause a great number of damages to the environment in different ways including waste production that lead to water, air and soil pollution. Some of these wastes are known to produce toxins capable of leaching over time, leading to contamination of ground water (Fraklin Associates, 2010). Biodegradable plastic raw materials have been obtained from foodstuffs like maize, rice wheat, potato and others but the land requirement and competition in food and feed needs is yet another challenge (Jerez et al., 2007; Zeller et al., 2013).

Microalgae like Spirulina on the other hand do not require large, fertile land and long period for growth. Spirulina houses numerous types of nutrients including a protein content of up to $60 \%$ on dry weight (Becker, 2007) which makes them a viable alternative to land crops. Also, their ability to pick up nutrients from wastewater and grow is another good advantage. Zeller et al. (2013) who studied bioplastic and thermoplastic blends from Spirulina and Chlorella microalgae revealed interesting results from their study. They developed blends of microalgal biomass and polyethylene from glycerol plasticization which was most effective at ratio 4:1 biomass to glycerol. In the above study, Spirulina blended better with polyethylene when compared to Chlorella samples; however, Chlorella was reported to exhibit higher bioplastic properties. The good performers of Spirulina in terms of blends led to their conclusion that Spirulina is more desirable for commercial applications.

In terms of tensile strength, the study by Dianursanti et al. (2018) revealed that increasing quantity of glycerol (plasticizer) decreased the tensile strength of bioplastics made from Spirulina, however, all the various percentages of glycerol addition tested gave higher tensile strength when compared with commercial plastic bags.

\subsection{Biofertilizers}

Probably due to population rise and technological advancement, fertilizers are heavily utilized in modern agriculture to increase output, however, the heavy use of inorganic and chemical fertilizers could form a threat to human health and the environment (Win et al., 2018). Due to the aforementioned, efforts are being channelled into the exploitation of microorganisms as a more eco-friendly approach for conservational agriculture. Hence, biotechnological "tools" like microalgae, fungi, rhizobacteria which are able to live in beneficial association with higher plants are of great concern as potential sources of biofertilizer.

One good reason for using cyanobacteria as biofertilizers is their ability to fix nitrogen; these organisms are known to convert inorganic atmospheric nitrogen $\left(\mathrm{N}_{2}\right)$ into organic nitrogen which is easily utilized by higher plants (Kumar, 2016). Already, attempts have been made to use cyanobacteria in the promotion of the growth rate of rice in both Chile and India and the cyanobacteria indicated increased nitrogen accumulation efficiency in rice paddles (Singh et al., 2016).

El-Rheem et al. (2015) who studied the stimulant effect of Spirulina under low level nitrogen fertilization on wheat plant observed that increasing levels of Spirulina microalga from $25-100 \mathrm{ml} / \mathrm{L}$ under low levels of nitrogen fertilization resulted in an increase in growth and yield of wheat without any negative effect from the decreased rate of nitrogen fertilization.

In addition to the above, the authors carried out an intense literature search on different applications of Spirulina globally in recent years reported by numerous reputable papers. The information is summarized in Table 1 below.

\section{Conclusion}

This review highlights the trend in Spirulinaresearch and modern applications of Spirulina, and also, it has equally shown how important the microalga is to humans, livestock and the environment. Since these applications involve key areas of humanity and the environment, Spirulina appears a recommendable candidate, not just for medicines but also for food, biodiesel, cosmetics, bioplastics and biofertilizer production. In this age of environmental pollution and higher population, increased production of Spirulina and its conservative use will do humanity a lot of good. Efforts like Spirulina mass farming in landlocked countries and safe laboratory multiplication could increase its availability since some studies have already shown encouraging health potentials from microalgae clones. Isolation and studies on all yet to be known compounds in Spirulina are open areas for new research. 
Table 1. Recent Findings on different Uses of Spirulina Documented in Different parts of the World over the last two Decades (2000-2020)

\begin{tabular}{ll}
\hline S/No & Research Aspect \\
\hline $1 . \quad \begin{array}{l}\text { Phytoremediation potential } \\
\text { of Spirulina (biosorption } \\
\text { and toxicity evaluation of } \\
\text { Cadmium) }\end{array}$ \\
2. & $\begin{array}{l}\text { Antioxidant properties un- } \\
\text { der different temperature }\end{array}$ \\
and nitrogen regimes \\
Antioxidant activity and \\
hepatoprotective effects of \\
Whey and Spirulina In vi- \\
tro and using rat model
\end{tabular}

4. Effect of Spirulina Bio-fertilizer on growth and yield of Vigna radiata

5. Bioplastics and their thermoplastic blends from Spirulina and Chlorella

$\begin{gathered}\text { Country/ } \\ \text { Region }\end{gathered}$
Major Finding(s)
Thailand Environmental factors were observed to have effect on biosorp-
tion. The optimum pH for biosorption of cadmium was 7. Rapid
Cadmium uptake with $78 \%$ metal sorption in 5minnutes as the
maximum Cadmium adsorption ability of Spirulina was 98.04mg
Cadmium per biomass.

Brazil Temperature of $35^{\circ} \mathrm{C}$ and sodium nitrate of 1.875 or $2.5 \mathrm{~g} . \mathrm{L}^{-1}$ had higher activity

Egypt In vitro findings indicated a dose-dependent trend in antioxidant, metal-chelating and radical scavenging activities. Both natural products prevented liver damage by $\mathrm{CCL}_{4}$ but more pronounced effects recorded in rats that received a mixture of Spirulina and Whey.

Myanmar The highest leaf area index, leaf area ratio, crop growth rate, relative growth rate, maximum total dry matter, harvest index and yield were found in crops administered $7 \mathrm{~g} / \mathrm{L}$ of Spirulina suspension

Georgia Spirulina indicated a good blend performance

Reference

Rangsaya-

torn et al.

(2002)

Colla et al. (2007)

Gad et al. (2011)

Agung $(2011)$

Zeller et al. (2013)

Indonesia Higher flavonoid and phenolic contents in dried compared to fresh Spirulina. Lower $\mathrm{IC}_{50}$ for antioxidant test in dried compared to the fresh state.

India Water extracts of Spiruina had a higher activity than methanol, ethanol and acetone

Agustini et al. (2014)

7. Antibacterial activity (In Vitro)

8. In Vitro Antibacterial activity Bangladesh Inhibition of bacterial growth

9. $\quad$ Antimicrobial (In vitro)

10. Antioxidant and anticancer activity

11. Effect of Spirulina on Wheat plants under low levels of Nitrogen

12. Optimization of protein extraction of Spirulina for generation of potential coproduct and biofuel

13. Effects of cosmetic containing Spirulina extract on young and mature skin

14. Attached cultivation for improvement of Spirulina biomass productivity

15. Microalgae cultivation for biosurfactant production

16. Mitigation of oxidative stress and repro-toxicity caused by Sodium arsenite in male rats
India Effective against bacteria and fungi

Egypt Highest antioxidant activity and total phenolic content was recorded at highest concentration tested. IC $_{50}$ of 18.8 and $22.3 \mu \mathrm{g} /$ $\mathrm{mL}$ was recorded for HCT116 and HEPG2 respectively.

Egypt Increase of Spirulina from 25 to $50 \mathrm{ml} / \mathrm{L}$ under low levels of nitrogen fertilization increased both the growth and yield of wheat.

Georgia High protein yield $(60 \%)$, Higher protein content in co-product $(80.6 \%)$ while the residual biomass was lower in nitrogen content and higher in total non-protein content than the original biomass

Brazil Increased stratum corneum water content in adult and young groups given Spirulina cream. Significant reduction in the sebum content on volunteers' skin as well as an improvement in skin microrelief by reduction in surface roughness. More homogenous and uniformly distributed keratinocytes.

China High footprint areal biomass productivity of $60 \mathrm{~g} / \mathrm{m}^{2} / \mathrm{d}$ was recorded. Similar nutritional content was found in the Spirulina cultivated with the new technique.

Brazil Spirulina and other tested microalgae demonstrated potentials as organic natural sources of for triggering both microorganism growth and biosurfactant production.

Saudi Spirulina dose of $300 \mathrm{mg} / \mathrm{kg}$ decreased induced oxidative stress, Arabia sperm abnormalities and testicular damages by its antioxidant potential.
Chakrabort y et al. (2014)

Ahsan et al (2015)

Usharani et al. (2015)

Zaid et al. (2015)

El-Rheemkh et al. (2015)

Parimi et al. (2015)

Delsin et al. (2015) 
17. Evaluation of the wound healing and antioxidant activity of Spirulina extract added into skin cream (In

18. Application of Spirulina on ice cream and soft cheese

19. Dietary supplementation with Spirulina and Garlic in Tilapia feed

20. Effect of the addition of various Spirulina concentrations into dried noodle

21. Effects of dietary supplementation of Spirulina and Chlorella on blood parameters of diabetic rats vitro test) and their sensory analysis

Turkey $0.1 \%$ of Spirulina extract gave higher proliferation activity compared to the control group with $198 \%$ cell viability after day 3 . The skin cream with $1.125 \%$ crude extract of Spirulina demonstrated enhanced wound healing effect on HS2 keratinocyte cell line.

Indonesia Addition of $1 \%$ and $1.2 \%$ Spirulina was observed as the best con-

Biodiesel production from Bangladesh Optimum condition for maximum esterification yield was found Spirulina

23. Effect of glycerol plasticizer in Spirulina based bioplastic

24. Spirulina as a tool against water pollution by $1,1^{\prime}-(2,2,2$-trichloroethane-1,1-diyl) bis(4-chlorobenzene); DTT

25. Spirulina in the treatment of fish farming wastewater

26. Spirulina growth in photobioreactor under varied nitrogen concentration for maximised biomass, carotene and lipid contents

27. Nutritional analysis of Spirulina

28. Effect of Spirulina on radiation-induced thyroid disorders and alteration of reproductive hormones

29. Effects of Spirulina on the chemical, microbial and sensory properties of wheat flour pesta

30. Antioxidative activity and phytochemical screening of Spirulina platensis, moringa oleifera and their synergies centrations for incorporation into soft cheese and ice cream respectively.

Egypt The mixture of Spirulina and Garlic significantly improved feed intake, live weight gain, specific growth rate, protein efficiency ratio and feed conversion ratio. The group also exhibited up-regulation of some immune related genes (TNF- $\alpha$ and liver hepcidin) and also recorded the least total mortality after bacteria challenge.

Indonesia Dried noodles administered 9\% Spirulina gave significant effect in elasticity; water, protein, $\beta$-carotene, fat, carbohydrate, ash content and sensory (hedonic) effects.

Iran Both Sprirulina alone and its combination with Chlorella increased the levels of white blood cells (WBC), red blood cells (RBC), platelet, packed cell volume (PCV), selenium and glutathione peroxidase (GPx) in diabetic rats. to be at the molar ratio of $12: 1$ and temperature of $60^{\circ} \mathrm{C}$. Biodiesel obtained were within standard limits when analysed with ASTM standards.

Indonesia Optimum plasticizer composition for the Spirulina bioplastic was $30 \mathrm{wt} \%$ with a tensile stress of $27.70 \mathrm{~kg} / \mathrm{cm}^{2}$ (close to commercial plastic bags) and $66 \%$ elongation.

Georgia 10ppm concentration of DDT is the acceptable for remediation by Spirulina in water. It was also observed that Spirulina removed about $70 \%$ of DDT after 15 days of incubation.

Agustini et al. (2016)

Abu-Ela-

la et. al.

(2016)

Agustini et al. (2017)

Emami \& Olfati (2017)

Rahman et al. (2017)

Dianursanti et al. (2018)

Kurashvili et al. (2018)

Brazil Maximum cellular density of Spirulina resulted in the production of $0.22 \mathrm{~g} / \mathrm{L}$ of dry biomass with a maximum productivity of $0.03 \mathrm{~g} / \mathrm{L}$. Ammonia, nitrate, nitrite and phosphate concentrations became lowered by more than $94.8 \%$.

Egypt Higher total carotene and total lipid contents were observed in nitrogen-limited condition

El Baky et al. (2019)

Indonesia Spirulina is a good nutritional source and a potential super food

Egypt Spirulina-treated group had a significantly attenuated oxidative caspase-3 activity.

Nogueira et al. (2018)

Liestianty

et al. (2019)

Ebrahim (2020)

Iran Different levels of Spirulina inclusion had a significant effect on chemical parameters of pasta. Sensory evaluation showed that pasta incorporated with $0.25 \%$ Spirulina had a higher acceptability as against the control.

Indonesia Significantly higher antioxidant activity in the combined crude and hexane fractions from Spirulina and Moringa (synergism). Some phytochemical groups were also detected more in the mixture of the two.
Mostolizadeh et al. (2020)

Nege et al. (2020) stress in thyroid tissues, ameliorated DNA damage and decreased 


\section{Acknowledgement}

Author N. A. S is grateful to the Ministry of Research, Technology and Higher Education, Indonesia and Airlangga University for a Master's scholarship with an enabling learning environment.

\section{Authors' Contribution}

Author N. A. S drafted and wrote the manuscript while authors M. E. D. and K. J. discussed the findings and supervised the process.

\section{Conflict of Interest}

All the authors of this review declare that they have no conflict of interest.

\section{Funding Information}

No direct funding was received for this work.

\section{References}

Abdulrahman, N. M., \& Ameen, H. J. H. (2014). Replacement of fishmeal with microalgae Spirulina on common carp weight gain, meat and sensitive composition and survival Pakistan Journal of Nutrition, 13(2), http://dx.doi. org/10.3923/pjn.2014.93.98.

Abu-Elala, N. M., Galal, M. K., Abd-Elsalam, R. M., Mohey-Elsaeed, O., \& Ragaa, N. M. (2016). Effects of dietary supplementation of Spirulina platensis and garlic on the growth performance and expression levels of Immunerelated Genes in Nile tilapia (Oreochromis niloticus). Journal of Aquaculture Research and Development 7:433. doi:10.4172/21559546.1000433.

Agrotech. (2012). Spirulina a live hood and a business venture. SF/2011/16. Funded by European Union. Implementation strategy of a Regional Fisheries Strategy for the Eastern-Southern Africa and India Ocean Region.http://www.fao. org/3/a-az386e.pdf

Agung, k. L. N. (2011). Effect of Spirulina Biofertilizer suspension on growth and yield of Vigna radiata (L.) Wilczek. Universities Research Journal, 4(1): 351-355

Agustini, T. W., Ma'ruf, W. F., Wibowo, B. A., \& Hadiyanto. (2017). Study on the effect of different concentration of Spirulina platensis paste added into dried noodle to its quality characteristics. IOP Conf. Ser.: Earth Environ. Sci. 55012068. doi:10.1088/1755-1315/55/1/012068

Agustini, T. W., Ma'ruf, F. W., Widayat., Suzery, M., Hadiyanto. \& Benjakul, S. (2016). Application of Spirulina platens is on ice cream and soft cheese with respect to their nutritional and sensory perspectives. Jurnal Teknologi (Sciences and Engineering), 78(42): 245-251. https://jurnalteknologi.utm.my/index.php/ jurnalteknologi/article/view/8216/4953

Agustini, T. W., Suzery, M., Sutrisnanto, D. Ma'ruf, W. F., \& Hadiyanto. (2014). Comparative study of bioactive substances extracted from fresh and dried Spirulina sp. International Conference on Tropical and Coastal Region Eco Development (ICTCRED-2014) Procedia Environmental Sciences, 23: 282-289. https://doi.org/10.1016/j. proenv.2015.01.042

Ahsan, S., Arefin, S., Munshi, J. L., Begum, N., Maliha, M., Rahman, S., Bhowmik, A. \& Kabir, S. (2015). In vitro antibacterial activity of Spirulina platensis extracts against clinical isolates of Salmonella enterica serovars Typhi and Paratyphi (SUBP03). Stanford Journal of microbiology; 5(1): 22-25. DOI: https://doi. org/10.3329/sjm.v5i1.26916

Ali, I. H., \& Doumandji, A. (2017). Comparative phytochemical analysis and in vitrom antimicrobial activities of the cynanobacterium Spirulina platensis and the green alga Chlorella pyrenoidosa: potential application of bioactive components as an alternative to infectious diseases. Bulletin de l'Ins t $i$ t u $t$ Scientifique, Rabat, Section Science de Vie, $\mathrm{n}^{\circ}$ 39, 4149. http://www.israbat.ac.ma/wp content/ uploads/2018/05/ALI_2018.pdf

Alves, M. J., Ferreira, I. C., Froufe, H. J., Abreu, R. M., Martins, A., \& Pintado, M. (2013). Antimicrobial activity of phenolic compounds identified in wild mushrooms, SAR analysis and docking studies. Journal of Applied Microbiology, 115(2): 346-57, http://orcid.org/0000-0002-8115-2713.

Amer, S. A. (2016). Effect of Spirulina platensis as feed supplement on growth performance, immune response antioxidant status of monosex Nile Tilapia (Oreochromis niloticus). Benha Veterinary Medical Journal, 30(1): 1-10. DOI: 10.21608/bvmj.2016.31332.

Ayala, F. (1998). Guía sobre el cultivo de Spirulina. In Biotecnología de Microorganismos Fotoautótrofos. pp. 3-20. Motril, Granada, España.

Barnett, M. (2007). Arthrospira platensis: Brief History and Description. Rolla. http://cites eerx.is t.ps u.edu/view doc/ load?doi=10.1.1.624.2581\&rep=rep1\&type=pdf

Bashandy, S. A. E., El Awdan, S. A., Ebaid, H., \& Alhazza. (2016). Antioxidant potential of Spirulinaplatensis mitigates oxidative stress and reprotoxicity induced by Sodium Arsenite in male rats. Oxidative Medicine and Cellular Longivity, 
Hindawi Publishing Corporation. 2016:1-8 http://dx.doi.org/10.1155/2016/7174351

Becker, E. W. (2007). Micro-algae as a source of protein. Biotechnology Advances, 25(2): 207-210

Berchmans, H. J., \& Hirata, S. (2008). Biodiesel production from crude Jatropha curcas L. seed oil with a high content of free fatty acids. Bioresource Technology, 99(6): 1716-1721. https://doi:10.1016/j.biortech.2007.03.051

Bermejo, R., Talavera, E. M., Alvarez-Pez, J. M., \& Orte, J. C. (1997). Chromatographic purification of phycobili proteins from Spirulina platensis. high-performance liquid chromatographic separation of their alpha and beta subunits. Journal of Chromatography A, 778: 44150.

Berthon, J., Nachat-Kappes, R., Bey, M. Cadoret, J., Renimel, I., \& Filaire, E. (2017). Marine algae as attractive source to skin care. Free Radical Research, 51(6): 555-567. https://doi.org/10.108 0/10715762.2017.1355550

Britz, P. J. (1996). The suitability of selected protein sources for inclusion in formulated diets for the South African abalone, Haliotis midae. Aquaculture, 140: 63-73. https://doi. org/10.1016/0044 8486(95)01197-8.

Brown, M. R., Jeffery, S. W., Volkman, J. K., \& Dunstan, G. A. (1997). Nutritional properties of microalgae for mariculture. Aquaculture, 151, 315-331. https://doi.org/10.1016/S00448486(96)01501-3

Chakraborty, B., Jayaswal, R. P. \& Pankaj, P. P. (2014). Evaluation of antibacterial activity of Spirulina platensis extracts against opportunistic pathogen model. International Journal of Pharmacognosy and Phytochemical Research, 6(4); 988-990. www.ijppr.com

Chojnacka, K., Chojnacki, A., \& Górecka, H. (2005). Biosorption of $\mathrm{Cr} 3+, \mathrm{Cd} 2+$ and $\mathrm{Cu} 2+$ ions by blue green algae Spirulina sp.: kinetics, equilibrium and the mechanism of the process. Chemosphere, 59: $75-84$. https://doi. org/10.1016/j.chemosphere.2004.10.005

Cliferri, O. (1983). Microbial Reviews, 47 (4), 551-578.

Colla, 1. M., Furlong, E. B., \& Costa, J. A. V. (2007). Antioxidant properties of Spiruina (Arthrospira) platensis cultivated under different temperatures and Nitrogen regimes. Brazilian Archives of biology and Technology, 5(1): 161-167. https:// doi.org/10.1590/S1516-89132007000100020

Colla, L. M., Reinehr, C. O., Reichert, C., \& Costa J. (2007). Production of biomass and neutaceutical compounds by Spirulina platensis under different temperature and Nitrogen regimes. Bioresource Technology, 98: 489-1493. https://doi. org/10.1016/j.biortech.2005.09.030

Dagnelie, P., Van Staveren, W. A., \& Van den Berg, H. (1991). Vitamin B-12 from algae appears not to be bioavailable. American Journal of Clinical Nutrition, 53: 695-697.https://doi.org/10.1093/ ajen/53.3.695

Delsin, S, D., Mercurio, D. G., Fossa, M. M. \& Maia Campos, P. M. B. G. (2015). Clinical efficacy of dermocosmetic formulations containing Spirulinaextract on young and mature Skin: effects on the skin hydrolipidic barrier and structural properties. Clinical Pharmacology Biopharmaceutics, 4: 144. doi:10.4172/2167065X.1000144.

Demirbas, A. (2009). Progress and recent trends in biodiesel fuels. Energy conversion and Management, 50 (1): 14 - 34. https://doi. org/10.1016/j.enconman.2008.09.001

Demule, M. C. Z., Decaire, G. Z., \& Decano, M. S. (1996). Bioactive substances from Spirulina platensis (cianobacteria). International Journal of Experimental Botany, 58: 93-96.

Deng, X., Fang, Z., \& Liu, Y. H. (2010). Ultrasonic transesterification of Jatropha curcas L. oil to biodiesel by atwo-step process. Energy Conversion and Management, 51(12): 2802-2807. https://doi.org/10.1016/j.enconman.2010.06.017

Dianursanti., Gozan, M., \& Noviasari, C. (2018). The effect of glycerol addition as plasticizer in Spirulina platensis based bioplastic. E3S Web Conferrence, 67, 03048. https://doi.org/10.1051/ e3sconf $/ 20186703048$

Dillon, J. C., Phuc, A. P., \& Dubacq, J. P. (1995). Nutritional value of the alga Spirulina. World Review of Nutrition Dietetics,77:32-46. doi:10.1159/000424464

Dwivedi, S. (2012). "Bioremediation of Heavy Metal by Algae: Current and Future Perspective. Journal of Advanced Laboratory Research in Biology, 3(3): 195-199, www.sospublication.co.in.

Ebrahim, R. M. (2020). Prophylactic effect of Spirulina platensis on radiation-induced thyroid disorders and alteration of reproductive hormones in female albino rats. International Journal of Radiation Research, 18(1). DOI: 10.18869/acadpub. ijrr.18.1.83

El Baky, H. H. A., El Baroty, G. S., \& Mostafa, E. M. (2019). Optimization growth of Spirulina (Arthrospira) platensisin photobioreactor under varied Nitrogen concentration for $\mathrm{max}$ i mi ze d biomass, carotenoids and lipid contents. Recent patents on Food, Nutrition and Agriculture, 10,00-00. DOI:10.2174/22127984106661812271 


\section{9}

EI-Sheekh, Mostafa, M., Daboor, S. M., Swelin, M. A., \& Mohamed, S. (2014). Production and characterization of antimicrobial active substance from Spirulina platensis. Iranian Journal of Microbiology, 6(2): 112-119.https://www.ncbi. nlm.nih.gov/pubmed/25705362.

El-Rheemkh, A., M., Zaghloul, S. M., \& Essa, E. (2015).The stimulant effect of the Spirulina algae under low levels of Nitrogen fertilization on wheat plants grown in sandy soils. International Journal ChemTech Research, 8 (12): 87-91.http:// www.sphinxsai.com/2015/ch_vol8_no12/1/(8792)V8N12CT.pdf

El-Sayed, A. F. M. (1994). Evaluation of soybean meal, Spirulina meal and chicken offal meal as protein sources for silver seabream (Rhabdosargus sarba) fingerlings. Aquaculture, 127:169-176, doi:10.1016/00448486(94)90423-5.

El-Sheekh, M., El-Shourbagy, I., Shalaby, S., \& Hosny, S. (2014). Effect of Feeding Arthrospira platensis (Spirulina) on Growth and Carcass Composition of Hybrid Red Tilapia (Oreochromis niloticus x Oreochromis mossambicus). Turkish Journal of Fisheries and Aquatic Sciences, 14(2): 471-478. DOI : 10.4194/1303-2712-v14_2_18

Emami, S. \& Olfati, A. (2017). Effects of dietary supplementing of Spirulina platensis and Chlorella vulgaris microalgae on hematologic parameters in Streptozocininduced diabetic rats. Iranian Journal Pediatric Hematology and Oncology, 7(3): 163-170. http:// ijpho.ssu.ac.ir/article-1-323-en.html

Fairchild, C.D\& Glazer,A.N.(1994).Nonenzymaticbilin addition to the $\alpha$ subunit of anapophycoerythrin. Journal of Biological Chemistry, 269:2898828996. https://pdfs.semanticscholar.org/7f94/ f4e07496786ee9bccbe5cd9ac82f0f90e524.pdf

Fraklin Associates. (2011). Cradle-to-gate life inventory of nine plastics resins and four polyurethane precursors. The plastics division of the American Chemistry Council, Franklin Associates, a division of Eastern Research Group, Inc., Prairie village, Kansas, pp 572. https://plastics. americanchemistry.com/LifeCycle-Inventoryof-9 Plastics-Resins-and-4 PolyurethanePrecursors-Rpt-Only/

Gad, A. S., Khadrawy, Y. A., El-Nekeety, A. A., Mohamad, S. R., Hassan, N. S., \& AbdelWahhab, M. A. (2011). Antioxidant activity and hepatoprotective effects of whey protein and Spirulina in rats. Nutrition, 1-8. doi: 10.1016/j. nut.2010.04.002
Glazer, A.N. (1988). Phycobiliproteins. Meth. Enzymol. 167, 291-303.

Grawish, M. E. (2008). Effects of Spirulina platensis extract on Syrian hamster cheek pouch mucosa painted with 7,12 -dimethylbenz[a] anthracene. Oral Oncolology, 44: 956-62.

Gunes, S., Tamburaci, S., Delay M. C., \& Gurhan, I. D. (2017). In vitro evaluation of Spirulina plaensis extract incorporated skin cream with its wound healing and antioxidant activities. Pharmaceutical Biology, 55(1): 1824-1832 doi: 10.1080/13880209.2017.1331249

Hoseini, S. M., Khosravi-Darani, K., \& Mozafari, M. R. (2013). Nutritional and medicinal applications of Spirulina microalgae. In: Minireviews in Medicinal Chemistry, 13: 1231-1237. Bentham Science Publishers. DOI:10.2174/1389557511313080009

Ibrahem, M. D., Mohamed, M. F. \& Ibrahim, M. A. (2013). The role of Spirulina platensis (Arthrospira platensis) in growth and immunity of Nile tilapia (Oreochromis niloticus) and its resistance to bacterial infection. Journal of Agricultural Science, 5(6): 109, DOI:10.5539/ jas.v5n6p109.

Iles, A., \& Martin, A. N. (2012). Expanding bioplasstics production: sustainable business innovation in the chemical industry. Journal of Cleaner Prodution, 45: 38-49. http://dx.doi.org/10.1016/j. jclepro.2012.05.008.

Jerez, A., Partal, P., Martínez, L., Gallegos, C., \& Guerrero, A. (2007). Protein-based bioplastics: effect of thermo mechanical processing Rheologica Acta, 46: 711-720. DOI 10.1007/ s00397-007-0165-z

Kataoka, N., \& Misaki, A. (1983). Glycolipids isolated from Spirulina maxima: structure and fatty acid composition. Agricultural and Biological Chemistry, 47(10): 2349-2355.doi:10.1080/0002 1369.1983.10865944

Katircioglu, H., Beyatli, Y., Aslim, B., Yüksekdag, Z., \& Atici, T. (2005). Screening for antimicrobial agent production of some microalgae in freshwater.The Internet Journal of Microbiology, 2: 1-5. https:// doi.org/10.5580/17b8.

Khan, Z., Bhadouria, P., \& Bisen, P.S. (2005). Nutritional and therapeutic potential of Spirulina. Current Pharmaceutical Biotechnology, 6: 373-379. https://doi.org/10.2174/138920105774370607

Klatt, J.M.,Al-Najjar, M. A.A., Yilmaz, P.,Lavik, Gaute., Beer, D., \& Polerecky, L. (2015). Anoxygenic photosynthesis controls oxygenic photosynthesis 
in a cyanobacterium from a sulfidic Spring. Applied and Environmental Microbiology. 81(6) DOI: 10.1128/AEM.03579-14

Koru, E. (2012). Earth Food Spirulina (Arthrospira): Production and Quality Standarts, F o o d Additive, Yehia El-Samragy (Ed.), ISBN: 978953-51-0067-6, In Tech, Available from: http:// www.intechopen.com/books/food-additive/ earth-food spirulina-arthrospira p r o d u c t i o n and quality standarts

Kumar, N. (2016). Effects of algal bio-fertilizer on the Vigna radiata: A critical review. International Journal Engineering Research and Applications 6 (2): 85-94. http://www.ijera.com/papers/Vol6_ issue2/Part\%20\%201/M62018594.pdf

Kurashvili, M., Varazi, T., Khatisashivili, G., Gigolashvili, G., Adamia, G., Pruidze, M. \& Gordeziani, M. (2018). Blue-green Spirulina as a tool against water pollution by $1,1^{\prime}(2,2,2$ trichloroethane-1,1-diyl) bis(4-chlorobenzene) (DDT). Annals of Agrarian Science, 16: 405 409. https://doi.org/10.1016/j.aasci.2018.07.005

Lanlan, Z., Lin, C., Junfeng, W., Yu, C., Xin, G., Zhaohui, Z. \& Tianzhong, L. (2015). Attached cultivation for improving the biomass productivity of Spirulina platensis. Bioresource Technology; 181:136-142.https://doi.org/10.1016/j. biortech.2015.01.025

Lauritano, C., Andersen, J. H., Hansen, E., Albrigtsen, M., Escalera, L., Esposito, F., Helland, K., Hanssen, K. Ǿ., Romano, G., \& Ianora, A. (2016). Bioactivity screening of microalgae for antioxidant, anti-inflammatory, anticancer, anti-diabetes, and antibacterial activities. Frontiers in Marine Science, 3: 68. doi: 10.3389/ fmars.2016.00068.

Liestianty, D., Indah, R., Rugaiyah, A. A., Asma, A., Patimah, Sundari, \& Muliadi. (2019). Nutritional analysis of Spirulina $s p$ to promote as super food candidate. IOP Conference Series.: Materials Science and Engineering 509012031. doi:10.1088/1757-899X/509/1/012031

Macias-Sancho, J., Poersch, L. H., Bauer, W., Romano, L. A., Wasielesky, W., \& Tesser, M. B. (2014). Fishmeal substitution with Arthrospira (Spirulina platensis) in a practical diet for Litopenaeus vannamei: effects on growth and immunological parameters. Aquaculture, 426: 120-125. https:// doi.org/10.1016/j.aquaculture.2014.01.028

Manigandan, M. \& Kolanjinathan, K. (2017). Antibacterial activity of various solvent extracts of Spirulina platensis against human pathogens. Innovare Journal of Health Sciences; 5(1): 1012. http://orcid.org/0000-0002-8115-2713
Mata, T. M., Martins, A. A., \& Caetano, N. S. (2010). Microalgae for biodiesel production and other applications: A review. Renewable andSustainable Energy Reviews, 14(1): 217-232. doi:10.1016/j.rser.2009.07.020

Mendiola, J. A., Jaime, L., Santoyo, S., Reglero, G., Cifuentes, A., Ibanez, E. \& Senorans, F. J. (2007). Screening of functional compounds in supercritical fluid extracts from Spirulina platensis. Food chemistry, 102: 1357-1367. doi:10.1016/j.foodchem.2006.06.068

Mostolizadeh, S., Moradi, Y., Mortazavi, M. S. \& Motallebi, A. A. (2020). Effects of incorporation Spirulina platensis (Gomont, 1892) powder in wheat flour on chemical, microbial and sensory properties of pesta. Iranian Journal of Fisheries Sciences, 19(1): 410-420.

DOI: $10.22092 /$ ijfs.2019.119107

Müling, M. (2000). Characterization of Arthrospira (Spirulina) strains. Durham Thesis, Durham University. Available at Durham E-Theses Online: http://etheses.dur.ac.uk/1198/

Murali, O. \& Mehar, S. K. (2014). Bioremediation of heavy metals using Sprirulina. nternational Journal Geology, Earth and Environmental Sciences, ISSN: 2277-2081. 4(1): 244-249.

http://www.cibtech.org/jgee.htm

Nakono, T., Yamaguchi, T., Sato, M., \& Iwama, G. K. (2003). Biological Effects of Carotenoids in Fish. In International Seminar Effective Utilization of Marine Food Resource, Songkhla, Thailand. pp. 1-15).

Nege, A. S., Masithah, E. D., Khotib, J. \& Ramadhan, R. (2020). Antioxidative activity and phytochemical screening of Spirulina platensis, Moringa leifera and their synergies. http://repository.unair.ac.id/ view/type/article.html

Nichols B. W., \& Wood B. J. B. (1968). The occurrence and biosyn thesis of y-linolenic acid in a blue-green alga, Spirulina platensis. Lipids 3: 46-50.

Nogueira, S. M. S., Junior, J. S., Maia, H. D., Saboya, J. P. S. \& Farias, W. R. L. (2018). Use of Spirulina in treatment of fish farming wastewater. Revista Ciencia Agronomica, 49(4): 599-606. https://doi. org/10.5935/1806-6690.20180068

Noman, S. (2018). Use of Spirulina in Fish Culture. A Seminar Paper Submitted to Bangabandhu Sheikh Mujibur Rahman Agricultural University, 1-31, http://bsmrau.edu.bd/seminar/wp c o n t e n t / uploads/sites/318/2018/05/Use-of-Spirulina-inFish-Culture-13-05-3016.pdf

Novak, A. C. (2010). Evaluation of the cosmetic 
of the Cyanobacterium Spirulina platensis.Universitéde Provence (AixMarseilleI),Brazil.https://pdfs.semanticschola r.cd/008492b0d6d7ccd68b664fc3674797cfa7 43. pdf

Olguín, E.J. (1986). Appropriate biotechnology systems in the arid environment. In H.W. Doelle, \& C.G. Helén, eds. Applied Microbiology.

O’Shaughnessy, J. A., Kelloff, G. J., Gordon, G. B., Dannenberg, A. J., Hong, W. K., Fabian, C. J., Dordrecht, D. Reidel Publ. Com., Paris, UNESCO, Trends in Sci. \& Res., 2: 111-134.

O’Shaughnessy, J. A., Kelloff, G. J., Gordon, G. B., Dannenberg, A. J., Hong, W. K., Fabian, C. J., Sigman, C. C., Bertagnolli, M. M., Stratton, S. P., Lam, S., Nelson, W. G., Meyskens, F. L., Otles, S. \& Pire, R. (2001). Fatty acid composition of Chlorella and Spirullina microalgae species Journal of AOAC International, 84(6): 17081714.

Otles, S., \& R. Pire. 2001. Fatty acid composition of Chlorella and Spirulina microalgae species. JAOACInt. 84: 1708-1714.

Parimi, N. S., Singh, M., Kastner, J. R., Das, K. C., Forberg, L. S. \& Azadi, P. (2015). Optimization of protein extraction from Spirulina platensis to generate a potential co product and a biofuel feedstock with reduced nitrogen content. Frontiers in Energy Research, 3:30. https://doi. org/10.3389/fenrg.2015.00030

Perry, J., Staley, J. \& Lory, S. (2002). Microbial Life. Sinauer Associates, Inc., p 768.

Rahman, M. A., Aziz, M. A., Al-Khulaidi, R. A. A., Sakib, N., \& Islam, M. (2017). Biodiesel production from microalgae Spirulina maxima by two step process: Optimization of process variable. Journal Radiation Research and Applied Sciences, 10: 140-147. http://dx.doi. org/10.1016/j.jrras.2017.02.004

Rangsayatorn, N., Upatham, E. S., Kruatrachue, M., Pokethitiyook, P. \& Lanza, G. R. (2002). Phytoremediation potential of Spirulinaplatensis (Arthrospira) platensisbiosorption and toxicity studies of Cadmium. Environmental Pollution, 119: 45-53. https://doi.org/10.1016/ S02697491(01)00324-4

Radmann, E. M., de Morais, E. G., de Oliveira, C. F., Zanfonato, K., Costa, J. A. V. (2015). Microalgae cultivation for biosurfactant production. African Journal of Microbiology Research, 9(47), 2283-2289.

Ravi, M., De, S. L., Azharuddin, S., \& Paul, S. F.
(2010). The beneficial effects of Spirulina focusing on its immunomodulatory and antioxidant properties. Journal of Nutrition and Diet Supplements, 2: 73- 83, https://doi.org/10.2147/NDS.S9838.

Reddy, C. M., Bhat, V. B., Kiranmai, G., Reddy, M. N., Reddanna, P., \& Madyastha, K. M. (2000). Selective inhibition of Cyclooxygenase- 2 by Cphycocyanin, a biliprotein from Spirulina platensis. Biochemical and Biophysical Research Communications, 277: 599-603. DOI:10.1006/ bbrc. 2000.3725

Roughan, P.G. (1989). Spirulina: A source of dietary gama-linolenic acid. Journal Science Food Agriculture, 47: 85-93.

Romay, C., Armesto, J., Ramerez, D., Gonzalez, R., Ledon, N., \& Garcia, I. (1998). Antioxidant og antiinflammatoriskeegenskaperavC-phycocyanin fra blågrønne alger. Inflammation Research, 47: 3641. DOI: $10.1007 / \mathrm{s} 000110050256$

Singh, J. S., Kumar, A., Rai, A. N., \& Singh, D. P. (2016). A precious bio-resource in Agriculture, ecosystem, and environmental sustainability. Frontiers in Microbiology, 7 : 529. doi: 10.3389/ fmicb.2016.00529

Tandeau de Marsac, N., and Cohen-Bazire, G. (1977). Molecular composition of cyanobacterial phycobilisomes. Proc. Natl. Acad. Sci. USA 74, 1635-1639.

Teimouri, M., Amirkolaie, A. K., \& Yeganeh, S. (2013). The effects of Spirulina platensis meal as a feed supplement on growth performance and pigmentation of rainbow trout (Oncorhynchus mykiss). Aquaculture, 396: 14-19, https://doi. org/10.1016/j.aquaculture.2013.02.009 .

Usharani, G., Srinivasan, G., Sivasakthi, S. \& Saranraj, P. (2015). Antimicrobial activity of $S p i r u l i n a$ platensis solvent extracts against pathogenic bacteria and fungi. Advances in Biological Research, 9(5): 292-298. DOI: 10.5829/idosi. abr.2015.9.5.9610

Whitton, B. A. \& Potts, M. (2000). Introduction to the cyanobacteria. In: Whitton, B. A., Potts, M (eds), The Ecology of Cyanobacteria. Kluwer, Amsterdam, (in press).

Widowati, I., Zainuri M., Kusumaningrum H. P., Susilowati R., Hardivillier Y., Bourgougnon N., \& Mouget, J. (2017). Antioxidant activity of three microalgae Dunaliella salina, Tetraselmis chuii and Isochrysis galbana clone Tahiti In: $2^{\text {nd }}$ International Conference on Tropical and Coastal Region Eco Development-IOP Conf. Series: Earth and Environmental Science doi:10.1088/1755 $1315 / 55 / 1 / 012067$ 
Win, T, T, Barone, G. D., Secundo, F. \& Fu, P. (2018). Algal biofertilizers and plant growth stimulants for sustainable agriculture. Industrial Biotechnology, 14 (4). Mary Ann Liebert, Inc. https://doi.org/10.1089/ind.2018.0010

Zaid, A. A. A., Hammad, D. M. \& Sharaf, E. M. (2015). Antioxidant and anticancer activity of Spirulina
Pharmacology, 11(7): 846-851@Asian Network for Scientific Information. DOI: 10.3923/ ijp.2015.846.851

Zeller, M. A., Hunt, R., Jones, A., \& Sharma, S. (2013). Bioplastics and their thermoplastic blends $\mathrm{f} \mathrm{r}$ o $\mathrm{m}$ Spirulina and Chlorella microalgae. Journal of Applied Polymer Science, $\quad$ 130(5): 3263-3275. https://doi.org/10.1002/app.39559. 